\title{
YOUTH COURTS: EXISTING AND PROPOSED
}

\author{
Benedict S. Alper*
}

\section{The Adolescent Offender}

Eighteen- and nineteen-year-old youths are soon to be conscripted for service with the armed forces. The reasons most commonly proffered for the desirability of conscripting boys in their latter 'teen years are their prime physical condition, their lack of emotional or economic family ties, their sense of adventure and daring, and the facility with which they adjust to new routines and the demands of a strenuous program of discipline and training. These are the attributes of youth, the potential. materials out of which may be fashioned splendid fighting men in time of war, or, in time of peace, recruits for the army of lawbreakers and criminals-or decent citizens.

There are two basic reasons for the interest recently displayed in the problem of the youthful offender: the first is the realization that criminality among older adolescents frequently takes the form of offenses of a violent or socially disturbing nature; ${ }^{1}$ the second is the general acknowledgment that the criminal court has failed to meet the challenge of modern life, especially as an instrument for understanding and influencing human behavior. In this latter connection, we find the growing conviction that the twentieth-century device of the children's court may contain within it the germs of an idea which may more successfully cope with the problem of social misconduct, especially in the adolescent age group.

\section{Adolescents in the Juvenile Court}

Recent years have seen the extension of the age jurisdiction of many of our juvenile courts beyond the sixteenth or seventeenth year. At the present time the juvenile court has control over delinquent boys up to the age of 18 , in 20 states and parts of four others. In 20 of these, jurisdiction is over all offenses without exception. Four states and part of one other give to the juvenile court jurisdiction in delinquency cases between the ages of $\mathrm{I} 8$ and $2 \mathrm{I}$. In the largest majority of states-30 and parts of three others-the juvenile court may retain jurisdiction up to the age of 2 I on con-

- A.B., 1927, Harvard College; 1932-1933, Institute of Criminal Law, Harvard Law School. Field Secretary, American Parole Association, New York. Research director to the New York State Joint Legislative Committee on Children's Court Jurisdiction, I94I; formerly research criminologist, Judge Baker Guidance Center, Boston. Author: Young People in the Courts of New York State (Albany, 1942); Criminal Youth and the Borstal System (New York, r94T) (with William Healy, M.D.); contributor to various journals on delinquency and related problems.

${ }^{I}$ See Sellin, Youth and Crime, supra, at p. 581 . 
tinuance of the case after the child has passed the age limit for acquiring jurisdiction in the first instance.

In four states, the adult criminal court has concurrent jurisdiction with the juvenile court in cases of delinquents between the ages of 18 and 21 . In 23 states the juvenile court may waive jurisdiction in delinquency cases between those ages. Finally, five states permit the adult criminal court to waive jurisdiction and allow the juvenile court to hear the case.

The number of courts specially created for adolescents is not large, but proposals are now being advanced which look to a marked increase in their number. Before turning to a consideration of these proposals, the courts already existing will be reviewed, together with some courts of general criminal jurisdiction which have devised special procedures for dealing with adolescent defendants.

\section{Existing Courts for Adolescents}

Chicago. The Boys' Court of Chicago, established in rgr4, is a branch of the Municipal Court and has jurisdiction over misdemeanors and quasi-criminal offenses committed by boys between the ages of $I 7$ and $2 \mathrm{r}$. In some cases the court also takes jurisdiction over adults involved with boys in this age group. Pre-hearing procedure is little different from the police handling which adult offenders experience, although some segregation of this age group is made in a part of the county jail. While the Boys' Court receives complaints of parents and others regarding cases which may be deemed to be wayward minors, who are handled informally by the court and the social agencies connected with it, the bulk of its work is with criminal offenses. Some of these misdemeanors and felonies are reduced to lesser offenses in order that they may come properly under the jurisdiction of the court. This determination is evidently made by an intake officer specially assigned to examine the case and to recommend disposition. In most cases, defendants charged with felonies are held for preliminary examination, and if probable cause is found, they are bound over to the grand jury.

Rotation of judges who preside over the Boys' Court, as well as the large number of cases with which they are daily confronted, hardly assures the desirable specialization of supervision or the necessary degree of individualization of treatment. Representatives of religious organizations carry the largest share of supervision. The probation officers employed in this court also supervise adult cases, and this fact, coupled with the inadequacy of investigation prior to hearing, casts some doubt on the efficacy of the court's procedure.

Philadelphia. The Municipal Court of Philadelphia, under authority of a legislative act passed in $1915^{2}$ has exclusive jurisdiction over cases of incorrigibles-runaway, disobedient, idle and disorderly youths $\rightarrow$ I6 to 20 years of age. To administer this jurisdiction, the Court created a Men's and a Women's Misdemeanant's Division with a procedure patterned very closely after that of the juvenile court. In September,

' Pa. Laws I9I5, No. IoI7, I7 PA. Stat. (Purdon, 1930) \$694. 
1939, the increase in the juvenile court age became effective ${ }^{3}$ and the cases between these ages were removed to the Juvenile Court Division of the Municipal Court where a separate session was created to deal with them.

After a youth has been arrested and the police discover that he is under 18 , he is brought directly to the juvenile court after he has been fingerprinted but not photographed or otherwise subjected to police investigation. The case is then assigned to a probation officer for preliminary interview. In practice, $70 \%$ are released on recognizance and the remainder held in custody, apart from younger children.

Investigation of cases involving minor offenses frequently discloses problems which can be corrected readily in their incipient stages, thereby safeguarding, both the offender and the community from further acts of delinquency. Likewise, treatment is determined by the problem of the offender rather than by imposing a specific penalty for a given offense. In short, the juvenile court has wider latitude in differentiating the treatment accorded to two individuals who have committed identi$\mathrm{cal}$ offenses. The length of institutional treatment is determined not by minimum or maximum penalties but by the offender's adjustment and readiness for return to the community. The law permits the commitment of any child over i6 years to any state industrial school or home for reformation and correction, with the result that security can be provided in the few cases in which it may be needed. Furthermore, the law grants additional flexibility by leaving to the discretion of the juvenile court judges the right to transfer the very serious offender to the criminal court for trial. During 1940, the cases of 14 boys and one girl, involving robbery, sex offenses, and homicide were so referred.

The district attorney selects the tribunal in cases of homicide; in all other cases of 16- and I7-year-olds, the jurisdiction is originally with the juvenile court. This session for older children is distinct and separate from the regular juvenile court. Attendance is limited to the necessary court personnel, the principals involved and representatives of interested social agencies.

A presenting attorney or court representative performs, in informal fashion, the same function as the district attorney-he asks many of the questions and otherwise helps in the proceedings. The reports which help to guide the judge in the hearing and disposition of cases are prepared by the probation officers who are directly responsible to the court representative and the case supervisor.

Almost 3,000 cases of I6- and I7-year-old defendants pass annually through this session of the juvenile court. It is interesting to compare the number placed on probation or committed to institutions in 1940 , under juvenile court jurisdiction, with those in 1938 before the age limit was raised. Statistics ${ }^{4}$ show that $14 \%$ of the total arrested $(2,294)$ resulted in commitment in 1938 as compared to $24 \%$ of the 1,959 arrests in 1940 , or a $46 \%$ increase. The difference in the number placed on probation was even more pronounced: 398 or $17 \%$ in 1938 as compared to $6 \mathrm{xr}$ boys and

${ }^{3}$ Pa. Laws x939, No. 226.

- Gathered by the Pennsylvania Committee on Penal Affairs. 
girls, or $32 \%$, in 1940 : nearly double the ratio. Such comparative results should resolve the question whether a non-criminal court procedure is too lenient for an adequate handling of the adolescent offender.

Detroit. Jurisdiction over "wayward minors" was conferred upon the juvenile courts of Michigan in $1927^{5}$ under a law which is very similar to New York's Wayward Minor Law, ${ }^{6}$ covering the age group I7 to 2 r. An additional clause not found in the New York law specifies as a wayward minor, a young person who "when not disabled from lawful occupation or study habitually idles away his or her time." Following the passage of this law, the Wayne County (Detroit) juvenile court established a separate department for the hearing of wayward minor cases. As far as is known, this is the only separate session for the hearing of wayward minor cases created anywhere in Michigan.

Proceedings in these cases, although conducted in juvenile court, are heard separate from the sessions for children. Temporary detention of wayward minors may be "to any institutions in the State having facilities for such cases," to private homes or to the custody of the county agent or an officer of the juvenile court. A county jail is in fact used in many instances, as the law specifies that facilities for the detention of children under 17 shall not be used for wayward minors over 17 , and to date no additional facilities have been made available for this latter group.

The hearing of wayward minor cases follows in general the procedure employed in children's cases by the juvenile courts of the state. Similarly, proceedings in these cases are not to be deemed criminal proceedings. The Wayward Minor Court makes use of the mental hygiene clinic which serves the juvenile division of the Court. Disposition may include probation as well as commitment to public institutions, private homes, or the custody of certain officers and private persons.

While the Wayward Minor Court has original jurisdiction over the cases described in this statute, very few of the cases so handled would actually fall into this category. The majority of the youths treated by the court have in fact violated the law and the regular criminal court could have taken jurisdiction. Due, however, to the close cooperation between this court and the district attorney's office, many of the boys with no previous records or with only non-serious records, are referred. This follows only after a conference has been held between the probation officer and the district attorney, and a determination has been made regarding the possibilities of satisfactory adjustment of the case under non-criminal court supervision. After referral, a thorough investigation into the boy's background and into the circumstances surrounding the case is made. If the original impression is confirmed that the boy should be treated as a wayward minor, an official complaint is filed in the juvenile court and proceedings are begun there.

In view of the fact that the statute defining the wayward minor is very specific, the complaint cannot alone allege that the youth has committed an offense; it must further charge him with one of the acts or conditions defining a "wayward minor."

E Mich. Coss. Laws (1930) $\$ 12838$.

- N. Y. Code CRIM. Proc. \$\$913a-913d. 
This procedure obviates any further contact with the criminal court unless the boy fails to adjust under the court's supervision, when he may be returned to the criminal court for prosecution. A formal complaint charging him with the commission of an offense then brings his case before the regular criminal court. This is not interpreted as placing him in double jeopardy, as all proceedings in the juvenile court are completely non-criminal.

Michigan authorities feel that the original jurisdiction of the court should be broadened to include all first offenders between $I 7$ and $2 I$ who are charged with a criminal offense, instead of relying, as they now do, upon the prosecutor's office to refer cases to them. There is a close parallel between this desire for a direct and completely legal jurisdiction over the youthful offender and the sentiment expressed in New York State for clear-cut legislative sanction as a basis for treating this age group in socialized fashion.

Brooklyn. Pursuant to a resolution adopted by the Board of City Magistrates, the Adolescents' Court was begun in Brooklyn on January $\mathbf{r}$, 1935, with a formal dedication by Mayor LaGuardia. ${ }^{7}$ One week later the first cases of youths were heard in this newly created court. The procedure has changed from time to time but essentially it has remained the same since its inception. In the first place it is limited to boys 16,17 and 18 years of age who come to the attention of the court by means of a formal complaint filed by an arresting officer or other complainant. Detention is in a separate wing of the borough jail. Nothing in this procedure alters the police handling of adolescent cases, although some attempts, not always successful, are made to keep them apart from adults. On the day of his arraignmentusually not longer than 48 hours after arrest-the offender is brought from the jail where he has been remanded, or comes into court freely if he has been released on bail or on recognizance. Jail cases await arraignment in a special pen attached directly to the court. Hearings, until very recently, were conducted in the judge's chambers.

The decision of the court-whether to hold for special sessions or for the grand jury on the one hand, or to allow the substitution of a wayward minor complaint on the other-is frequently made without benefit of any preliminary investigation. This is perhaps the greatest weakness of this procedure. If the boy waives examination, he is held in jail or on bail for the court of special sessions or the grand jury and the papers in the case are forwarded to the proper authorities. If it is determined that he shall be held as a wayward minor, the procedure is explained to him and a return date is set for hearing on this new complaint.

The parent has already signed a complaint that the youth is a wayward minor and evidence is taken on this point at the wayward minor hearing. The mother or father then swears under oath that the boy is "morally depraved or in danger of becoming so" or is persistently disobedient to given lawful commands, whereupon the judge adjudicates the youth to be a wayward minor, and either suspends sentence

\footnotetext{
' Since 1936, a Wayward Minor Court has been in operation as a branch of the Magistratc's Court in adjoining Queens County. The similarities between the procedures in these two courts are of greater interest than any differences between them, for which reason the Queens plan is not here discussed.
} 
or places him on probation. The length of this probation period is usually not specified, but does not generally run beyond a year.

If at the completion of this loosely determined probation term the youth has responded well, he is discharged from further supervision and thus finds himself free from any criminal record. Adjudication as a "wayward minor" is comparable to finding a juvenile "delinquent" in the children's court: it is an adjudication of a status, not a conviction for a crime. If he violates the terms of his probation or commits a new offense, the youth may then be committed to an institution.

Upstate New York. Although the work of the Adolescents' Courts in Brooklyn and adjoining Queens has received a great deal of attention recently-at the hands of the New York Legislature ${ }^{8}$ as well as of students of court procedure elsewherethere are some recent trends in the criminal courts of upstate New York which are not without interest for this discussion. While no attempt has been made to test whether or not these various court devices for dealing with the adolescent offender are outside the strictly legal provisions of criminal court procedure, there is little doubt that much unheralded work of the same type may be discovered in other courts throughout the country. The various plans are here briefly described to demonstrate that not only is there a widespread desire to deal in non-criminal court fashion with the offender who is just above children's court age, but this desire has been in fact widely translated into practice. A great diversity of methods is the result. Most discussions of the adolescent offender will be found to overlook the problem outside of the large urban centers. It is an interesting commentary on our thinking in this field that all of the recognized court plans for adolescent cases are found in the large cities. This is further demonstrated in the limitation of the Youth Court.Act of the American Law Institute, described below, to "Metropolitan and Large Urban Centers"- a decided weakness of this plan.

The measure most frequently employed in these courts is the reduction of the charge in order to spare the youth a felony record, with all the disabilities which accompany that kind of a conviction. Judges of these courts have frequently stated their opinion that sentence to a penal institution is too extreme for most of the offenses which these youths commit. Yet in order to hold them under some kind of supervision it is necessary first to convict.

Therefore, in the cases of certain defendants 16,17 or 18 awaiting indictment, we find some county court judges first discharging the youth from jail and placing him in the custody of a probation officer. Were this not done, some of these boys might be detained for as long as six months awaiting action by a grand jury which may meet only twice a year. After indictment and on the date of the hearing, the judge then reduces a burglary indictment, for example, to a misdemeanor, such as unlawful entry, or takes a plea to a lesser offense. The boy is thus spared a felony record at the same time that he is held accountable in some measure for his offense, and does not entirely escape supervision.

${ }^{3}$ Cf. Young People in the Courts of New York State (fifth and final report of the New York State Joint Legislative Committee on Children's Court Jurisdiction), N. Y. Legrs. Doc. No. 55 (1942). 
Although some judges now employing this method choose to describe it as the ". . County plan," there is of course nothing unique about it. Judges have always had authority to release from jail in custody of an officer of the court (except in certain specified offenses) and the reduction of charges or acceptance of a plea to a lesser offense is as old as the realization in the criminal law that its rigors must somehow be relaxed in certain cases-which is a very long time, indeed.

Another county has developed a plan for boys 16 to 20 who have been indicted. At a conference of the district attorney, the judge and the chief probation officer, the trial list of all those in the age group who are known to be first offenders, is reviewed. On arraignment, if the youth is not represented, counsel is assigned and he is directed to plead "not guilty." Between the hearing and the trial an investigation is made with the consent of the boy and counsel. This investigation includes some reference to the circumstances of the offense. Another meeting is then held between the district attorney, the judge and the probation officer, at which time the court determines whether or not it will entertain a plea to a misdemeanor. Those charged with a second felony, with robbery, or with a crime where violence is involved are refused this privilege, as well as boys with long misdemeanor records; otherwise all indictable offenses involving youths 16 to 20 are subject to it.

The plan has certain obvious advantages: it assures youthful defendants of representation by counsel and spares deserving cases a felony conviction. Its weaknesses are also obvious: it comes into operation only after indictment, it has no effect whatsoever on the processes of apprehension, preliminary hearing or detention; it encourages hypocrisy by first requiring the youth to plead "not guilty" and subsequently to repudiate this plea; it depends entirely on the good will and social consciousness of the judge and the district attorney, and may be open, in certain instances, to abuse for reasons which may be euphemistically described as "expedient."

In a large upstate city court, about one third of the youthful defendants are handled by a special procedure. Upon a plea of guilty, where there are special "mitigating circumstances," and with the consent of the complainant, the probation officer makes an investigation into the youth's background. If the results of this investigation confirm the initial opinion that the case would not be best handled by means of a criminal conviction, the defendant is then permitted to withdraw his plea, and his case is discharged. This is done with the overt understanding that he will accept "voluntary" or "unofficial" probation upon discharge, which leaves the court, in actuality, no official control over him. Such an ending must seem to the youth to be something of an anti-climax, concluding, as it does, a court process which has allowed him-at least once-to reverse his plea.

In certain other cases in the same court-just how the differentiation is made, is not clear-consent is secured from the youthful defendant or his counsel (where he is represented) to waive his right not to be investigated prior to conviction. $\mathrm{He}$ further agrees to abide by the results of this investigation. When the investigation is completed, another hearing is held at which time the probation report is presented. 
If it is agreed that the case had best be handled "voluntarily" or "unofficially," the youth is discharged, after which the probation officer continues to supervise him.

It should be stated at this point that not only are these various commendable subterfuges employed in a limited number of cases, but the period of time in which the defendant is held for "unofficial" probation is likewise limited. Courts which have conceived these various plans are anxious-for obvious reasons--that their tenuous control over 'a discharged defendant not be extended for too long a period of time.

Another upstate county has evolved its special "system" for cases between the ages of $\mathrm{I} 6$ and 20. The application of this plan is limited to offenders who have no prior court record and who are not charged with a crime of violence. In a typical case, this procedure would operate as follows: A youth is indicted by the grand jury for larceny of an automobile. He is brought before the court, and the judge is informed that he has no prior record. The case is then put over for a week or ten days, the boy being released or continued on bail. Meanwhile he is interviewed as to his background, family situation, school and employment history. No aspect of the offense in question is examined into. When the probation officer files his report and it is discovered that there is some domestic difficulty, lack of parental supervision, poor companionship or the like, the judge suspends trial on the indictment, "to await the results of a final investigation." Then, with the consent of the boy, his parents, the district attorney, and usually the complainant, the boy is placed on "unofficial" probation. The case is again brought up at a later date-not too distant-and if satisfactory conduct is reported, the judge decides whether to accept a plea to a misdemeanor, or whether the district attorney will, with the consent of the judge, nol pros. If the boy fails on probation within what is considered to be-but is not clearly defined-a reasonable length of time, the case is tried in the usual manner.

One county court which makes a practice in certain felonies charged against youthful offenders, of taking reduced pleas to a misdemeanor, recently found itself confronted with a situation which made this procedure difficult, if not impossible, to continue. The district attorney had ruled that he would no longer recommend reduced pleas on any charges against any defendant, youthful or otherwise. This step had been taken in order, as he announced, to throw the responsibility for a reduced charge onto the judges themselves, and to avoid future criticism of his office. Many adolescents thus found themselves awaiting action by the grand jury because the magistrate could no longer reduce the charge against them from a felony to a misdemeanor which came within his jurisdiction for summary action. It was argued that such boys as could not secure bail "stood to gain" from a jail experience, which might "teach them a lesson"-even though the charges against them might later be dismissed. Such youths now find themselves held for an indictment on two counts for the same offense: one charge for a felony and one for a misdemeanor. Upon arraignment, the youth is usually persuaded to plead guilty to the latter, after which he is placed on probation.

This plan, with its contradictions of philosophy working at cross-purposes with 
procedure for the avowed benefit of the boy, operates actually to his detriment. Because the prosecutor's office desires to free itself from possible-or actual-criticism on the part of the electorate, the young defendant finds himself confronted with a felony charge, where it is admitted that a misdemeanor complaint could lie; he is committed to jail in order that he may be "taught a lesson" although a different "lesson" is learned from what is intended; and when magistrate, jail, grand jury and county court have finally ground out his case-and him-he finds himself under a term of probation and supervision for the misdemeanor which it is admitted could have been charged against him in the first instance.

The confusions and inconsistencies of these various plans, while they demonstrate a certain courage and ingenuity on the part of judges and court officers, nevertheless epitomize the difficulties of grafting a non-criminal procedure onto to the rigid and traditional procedures of the criminal court, with all of its safeguards for the protection of the individual. These measures are attempts to adapt the criminal court process, based as it is on a philosophy which is fundamentally punitive, to a realization of the necessity for using scientific methods of investigation and therapy for the rehabilitation of the offender. Unless we are willing to depart from the realm of the criminal court and to enter the equity, chancery, non-punitive realm- of the juvenile court, we will continue to rely upon extralegal makeshifts, to countenance a bastard procedure which is not consistently that of the criminal court and equally far removed from the socialized and clinical approach of the modern court for children.

\section{The Youth Court Act}

Thus we see that by one course or another, the age limit for non-criminal court dealing with the older adolescent offender is gradually being extended, whether within the juvenile court itself, or by some procedure patterned after it. This brings up the question whether we should rely upon this trend to care ultimately for all youthful offenders between the upper age limit of juvenile court jurisdiction and $2 \mathrm{I}$, or whether some special court instrumentality should be devised.

The American Law Institute has inclined away from this latter alternative:

The fault in this possibility, however, is that, though juvenile court procedure may be eminently suited to cases in which juveniles are involved and the court is acting merely in loco parentis, the Youth Court will not be dealing with juveniles. The offenses for which trials in this Court must be had will not be the minor offenses of ebullient or misdirected childhood; they will be arson, assault, burglary, grand larceny, robbery while armed, and even homicide. The consequences of erroneous conviction or acquittal of such crimes would be too serious to both the individual and the state to permit use of the informalities of procedure of the juvenile court-its disregard of rules of cross-examination, its disuse of formal accusations and trial by jury. Hence the prosecution process in these cases cannot safely be expedited by merely extending the juvenile court jurisdiction to cover them. ${ }^{0}$

\footnotetext{
- Youth Court Act (A. L. I., July I94I) pp. Io, Ir. Copies of the text of the Act, with the official commentary, may be obtained at the offices of the American Law Institute, 3400 Chestnut Street, Philadelphia. For a further discussion of the Act, see (1941) 18 Proc. A. L. I. 352-381.
} 
After the adoption of the Youth Correction Authority Act by the members of the American Law Institute, this body adopted a model act to establish youth courts in metropolitan and large urban centers. ${ }^{10}$ It is not so much a model statute as it is a declaration of fundamental principles drafted in the form of a specific act. It was drawn up by the same committee of experts who were responsible for the Youth Correction Authority Act; ${ }^{11}$ their preëminent standing commends the Youth Court Act to the attention of the professional worker as well as the public at large.

The Youth Court plan has two basic objectives: to shorten the time which now elapses between the arrest of the adolescent offender and the final disposition of his case, and to improve the conditions under which he is apprehended and detained. The Act is limited to offenders who are beyond the age of juvenile court jurisdiction but who are not yet $2 \mathrm{I}$.

The court organization calls for the-appointment of a chief justice and an unspecified number of associate judges, who are authorized to sit as examining magistrates as well as to try cases. This is done to eliminate the needless delay which now occurs in the hearing of a case because of division of responsibility between the courts charged with jurisdiction over the same offenses.

A relatively novel feature of the Act specifies the appointment by the Youth Court justices of a "presenting attorney" whose duties and functions go far beyond those of the prosecuting attorney. The presenting attorney is directly responsible to the court, and his duties include: collection and organization of evidence relating to allegations of violations of laws by persons within the age jurisdiction of the Court; cooperation with the police in securing evidence concerning the accused; determining - subject to approval of the judges of the Court-the propriety of further action against the youth; drafting accusations; performing in general-concerning youthsthe functions of the prosecuting attorney of the county; assisting the Court "in protecting society and the individual and in administering justice to the innocent as well as the guilty." This is one of the most important provisions of the Act.

The presenting attorney is required to furnish to the Youth Court, at least once a week, a list of all cases which have not been disposed of by discharge or final judgment together with information regarding the date of arrest, date of the initiation of the proceeding, and the state of the proceeding in each case. This requirement would go far to prevent a great deal of unnecessary delay in the passing of cases through the various steps from arrest to final disposition. It would be most difficult under this system for cases of adolescents to drag on untried, week after weeksometimes for two months and even into the third month-as is not unknown in many states.

The judge of the Court is empowered to appoint counsel for the youth, a public defender in effect, who "shall in all proper ways assist him in obtaining lawful judgment upon the merits of the case." Defense counsel is further permitted to enlist the

${ }^{10}$ Youth Court Act, supra note 9.

${ }^{11}$ For a list of the committee members, see Waite, The Youth Correction Authority Act, supra, at p. 600. 
services of the legal aid society or other voluntary defender organizations. The judges of the Youth Court are authorized to appoint an administrative officer to keep its records, to list and assign cases for hearing and trial, and in other ways to perform the functions of a chief clerk. He is also given supervision over plant and structures under the control of the Youth Court and the management of detention places. Because of the acknowledged harmful influences upon young defendants of the institution of the "bull-pen" in many courthouses, the justices of the Youth Court are authorized "to establish or approve for utilization appropriate places adjacent to court-rooms for safe custody of persons," and are authorized to visit and inspect all places used for detention.

Upon his arrest, any youth between the upper age limit of the juvenile court and 2I must "be delivered into the custody of an officer and one of the places of detention" authorized by the Court. Thereupon the supervisor of the detention place must at once notify the Youth Court, through the presenting attorney, that it is holding the youth in custody. Thereafter the presenting attorney must verify the age of the offender and investigate the charge against him. He is also given the right to be present in person or through a designated agent whenever the youth is examined by the police or by other agencies. Modern court practice recognizes that the shorter the interval between arrest and the first questioning, the more likely is the truth to be discovered. Furthermore, by giving the presenting attorney the right to be present during police custody some restraint is put upon the police in their possible use of abusive methods.

Some limit is placed upon the presenting attorney's power to nol pros by the requirement that he shall not only be of the opinion that the youth is innocent, but that he shall further enter in the records of the Court a full explanation of his reasons for his belief and action. The children's court-in New York City, for example-has instituted the procedure of dismissing a charge against a child upon certain conditions, and the presenting attorney is similarly permitted to recommend to the judge that proceedings be discontinued and the youth discharged.

In order to reduce or eliminate one of the most frequent causes for unnecessary delay-the time required for indictment by the grand jury-the Youth Court is authorized to try cases "upon accusation by information in writing signed and sworn to by the presenting attorney." Nothing in the Youth Court Act changes in any way the rights and privileges of youthful defendants to release on bail, to a preliminary hearing, to trial by jury, to counsel, to publicity of trial, to appeal and to all other rights, privileges and immunities.

Two chief criticisms may be made of the Youth Court Act. The first is that it still maintains, despite the many progressive features introduced, the procedure of the criminal court. There is no attempt to incorporate any of the modifications of the trial process which have so successfully been employed in the juvenile court. Were the Youth Court Act to be introduced into the court structure of many of the states, it might postpone for decades the gradual replacement of the criminal court process 
by a procedure which is better fitted to arrive at the truth of the offender's guilt or innocence, and is better equipped to approach his difficulties in non-punitive fashion.

The Act is furthermore designed particularly for "metropolitan and large urban åreas." While it is better to limit a valuable piece of court machinery to the cities than not to have it at all, the fact remains that too many social welfare devices have in recent years been similarly allocated. These large urban areas are at the same time the center of all kinds of private and public agency resources not found in the rural or less populous urban centers. It would appear that uniformity of court treatment should be extended to all the young people of a particular state, wherever they may commit their offenses, wherever they may be apprehended and brought into court. This takes on new urgency when it is realized that the Youth Court Act was designed as an adjunct to the Youth Correction Authority Act, relating only to the process of determining whether or not an accused youth has committed crime and should be subjected to the rehabilitative treatment of the Correction Act. ${ }^{12}$ For the Youth Correction Authority Act to be truly equitable and effective in its operation, it would appear essential that the material sent to it for treatment should arrive by the same process, after a hearing which represents in its fundamentals the same approach and attitude on the part of the court. If the Act were designed to make the Youth Court a part of existing juvenile courts in each state, three definite advantages would accrue: the creation of a distinctly new piece of court machinery would be obviated, the nature of the procedure of the court would be non-criminal and nonpunitive, the adoption of the act would be expedited because juvenile courts are now found in all but one state in this country.

Finally, the juvenile court has not been without far-reaching influence on penocorrectional thought and practice. The modifications and humanizing devices which have found their way into a few outstanding reform institutions for older offenders are a direct outgrowth of, and are more frequently found in, the institution for the treatment of the offender of juvenile court age. It is to be feared, were this Youth Court Act to be enacted, that these courts would have little or no progressive influence on the program and the attitude of our so-called reformatories for the older 'teen-age offender.

New York State Proposals

As the result of the efforts of the New York State Joint Legislative Committee on Children's Court Jurisdiction, bills were introduced this year in the state legislature calling for the creation of a youth court part of the Children's Court in New York City, ${ }^{13}$ and the creation of similar courts as a part of the children's court in each upstate county. ${ }^{14}$

The purpose of this legislation was to set up a piece of court machinery especially designed for the hearing of the cases of youthful offenders 16 to 19 , to attach it to the one non-criminal court dealing with behavior problems-the children's courtthus making it possible eventually to amalgamate the Youth Court and the Children's Court into one Minors' Court with a children's session and a youth part.

${ }^{22}$ Youth Court Act, supra note 9, at 7.

1s Sen. Intro. No. 485 (1942).

"Sen. Intro. No. 1423 (1942). 
These bills establish a fundamental principle which has the effect of reversing the irregular procedure which has existed hitherto in the cases of adolescents. Instead of having the cases of youths presented to the court by means of a criminal complaint, which must then somehow be set aside, these bills provide that such cases shall first be presented upon petition, in much the same manner as the cases of delinquent children now come before the children's courts. Instead of allowing the judge to make a determination as to whether or not a criminal complaint or a non-criminal wayward minor complaint shall lie, as is now done, frequently without the benefit of an investigation into the offender's history, background and condition, these bills specify that the probation report shall precede any such decision; that the youth shall have an opportunity to convince the court that the protective rather than the criminal procedure shall be followed, and that the district attorney shall also be heard. If the court determines, as a result of this hearing and of reports before it, that the offender shall be held as a youthful offender, the procedure remains entirely on a chancery basis. If the court is persuaded that the welfare of society and the condition of the youth require that he be held on the criminal side, the case may then be summarily disposed of-if it is a matter coming under the jurisdiction of a magistrate-or the youth may be held for a higher court or for indictment by the grand jury.

An important principle is here enunciated-that all youthful offenders who now come before the court shall first have an opportunity to be treated as the children's court now treats them-as young people "in need of aid, encouragement, and guidance." This is not sentimentality; it is not urged that a tender and careless procedure be introduced into our courts for the handling of the cases of youthful offenders. It places in the court system of the state a protective procedure which will give no special favor to anyone, because the granting of this protection is the privilege and right of every youthful defendant on his initial appearance before the court. At the same time, the interests of the public are safeguarded by permitting the case of a youthful defendant who requires to be treated by that method, to fall back into the stricter channels of the criminal law and criminal court procedure. Both procedures take place in the same court.

A new definition is added to the Children's Court Acts of the State-that of a "youth," to include persons 16,17 and 18 years of age. The reason for limiting the application of this Act to youths in these three years is because existing procedures in New York City for dealing with the adolescent offender have demonstrated that this is a fairly homogeneous group, containing a not over-large proportion of offenses of a violent nature.

Offenses which, if committed by adults, would be punishable by death or life imprisonment are exempt from the jurisdiction of this new court, as they have been in the children's court. This, together with the limitation of the Act to a three-year age group, are two obvious deficiencies of the bill. However, it was acknowledged that only a start was made with the bill's introduction: as with the juvenile court, age and offense jurisdiction would in time be extended.

At the other end of the scale, traffic offenses were also excluded because they are 
entirely regulative in nature and no moral element is involved. These now make up approximately two thirds of all the offenses for which youths $16, \mathrm{I} 7$ and $\mathrm{r} 8$ years of age are arrested in New York. Other infractions of regulations and ordinances are included because-as in the case of peddling, gambling, begging and similar violations-there may be some need for socialized treatment by the court of the conditions underlying such activity.

One of the most important and valid objections to the present criminal court dealing with youthful offenders is that youths are commingled with adult criminals. One section of the Act insulates such youths entirely from any adult coming into the family court. Furthermore, because the offenses committed by youths are more serious and their conditions more difficult than those of children brought before the court, youths are segregated from this younger group as well. A waiting room for youths is specified along with the provision that only the young person involved in a proceeding may be permitted in the court room.

"Any person" is permitted to initiate a proceeding in the Youth Court by filing a petition rather than a complaint, in order to bring a youth to the attention of the court by a non-criminal route. This definitely established the court's initial interest on the equity or chancery side, as in the children's court. This is one of the most essential features of the Act. In all the existing procedures for dealing with the adolescent offender in New York City-and upstate-cases of youths are referred to the court initially by means of a regular formal criminal complaint. The steps which these courts now take consist in the reduction of the complaint-by one questionable means or another-to the status of a wayward minor or some such other non-criminal basis.

The method specified in this bill is the very reverse of that found in existing procedures for adolescent offenders. All cases of youths brought to the attention of the Youth Court come in originally via non-criminal petitions. It will be seen later that where the court determines that such a petition shall not lie, the directing of the filing of a criminal complaint may be substituted. An additional requirement specifies that youths shall not be transported in any vehicle with an adult or a child who is under court control. This effectively removes youths not only from association with adults or children but, more important, permits their detention on a non-penal level through provision for remand to private homes, agencies or societies, or to the custody of private persons.

The bill requires that youths must be taken before a justice of the court immediately upon the return of a summons or immediately upon being taken into custody. This should reduce to a minimum the amount of time which a youth may spend in detention even though such detention no longer includes, as it did formerly, jails, lockups or other places where adults are confined. Police questioning, line-ups, fingerprinting and photographing, and possible brutality are all obviated by this provision.

The nub of the Act is that section providing for the court to make an important decision: whether the circumstances of the offense committed and of the youth's 
background merit his relief from criminal prosecution and his continuance on the petition that he is a youthful offender, or whether he shall not be so relieved and thereafter held on a criminal complaint. In its determination of a specific course among the several which it is authorized to make, the court is guided by the report of the probation officer, the results of other investigations-medical, psychological or psychiatric-and the recommendation of the district attorney. Once the district attorney has concurred in the decision that the youth should be relieved of criminal prosecution and continue to be held as a youthful offender, he and his role disappear entirely from this procedure. Through him the People have had their opportunity to decide whether or not the youth shall be held as a criminal, and, once waived, no further element of the criminal process enters into the procedure or deliberations of the Youth Court.

Adjudication as a "youthful offender" is tantamount to a finding that a child is a "juvenile delinquent." The various judgments which the court may then make are largely drawn from parallel provisions in the children's court code. If it is decided that the youth shall be held for criminal prosecution, the court is then empowered to direct the filing of a formal complaint. At the hearing on this complaint, the court is given several further alternatives: to exercise summary jurisdiction and render final judgment in accordance therewith, if the charge is one over which a magistrate has jurisdiction; to hold the youth for the court of special sessions; to bind him over to the grand jury; to discharge the case.

It is to be expected that the justice presiding at a hearing on the formal complaint will not be the same justice who presided at the hearing at which it was determined that a complaint should be filed in place of the youthful offender petition. However, this provision was not made mandatory in the law because it may not always be possible for the court to follow it. There are many instances in which a judge sits twice in the same case without in any way jeopardizing a particular defendant's right to an unbiased and unprejudiced trial.

In those instances where the youth is held for a higher court or for the grand jury, only such part of the record of the proceedings as was before the judge when he sat as a committing magistrate may be forwarded to the district attorney. This provision was included in order to avert the possibility that any part of the record-probation officer's report, prior criminal records, mental, physical or psychiatric examination, inquiry into the instant offense-would go up to the prosecutor's office, with the likelihood that the right of the youthful defender to a fair trial would thereby be prejudiced or endangered.

At any time in the proceeding, the youth may demand his right to be treated under the provisions of the criminal law, as if he were an adult. This is done to insure against the rare event of an appeal from the initial non-criminal procedure in the court, and to preserve the right to a trial by jury. He is likewise relieved from any further prosecution or penalty for the offense alleged in the petition upon which he was adjudicated a youthful offender. This procedure was clearly included in order to meet the constitutional safeguard against double jeopardy. 


\section{Conclusion}

There is a very definite move on foot in this country to recognize that youth is a period presenting peculiar characteristics, committing crimes, a large proportion of which are of an aggressive and violent nature, and representing at the same time a challenging and hopeful field for rehabilitation. The feeling grows that our criminal courts are not fitted for the hearing and trial of these cases, that existing inadequate detention methods plus the slow process of criminal justice increases the difficulties of later reform and presents to youthful offenders many opportunities for evading the proper action of the court.

Special courts for the trial of youth cases are not new. They have been in existence in at least four large American cities, in Chicago since 19r4. A wide diversity of schemes is also employed in behalf of adolescent offenders by various criminal courts, desirous of mitigating the full rigors of the criminal law. These allow the youth still to stand trial, and to be convicted technically by a process which is an evasion of the law at the same time that it is a commendable gesture on the part of certain judges who realize existing inadequacies.

The American Law Institute has drafted a model bill, companion to the better known Youth Correction Authority Act, known as the Youth Court Act. Advantages of the Act include: drastic reduction of the time between apprehension and trial; improvement of the conditions of apprehension and detention; establishment of the office of presenting attorney-a modification of the role of the district attorney who is at the same time a friend of the court-which is the most novel feature of the bill. The Act is designed chiefly for the larger metropolitan areas, and helps to perpetuate the dealing with the cases of youthful criminals by a criminal rather than by a non-criminal court. These are the two chief criticisms to be levelled against it.

In the light of these criticisms, two bills introduced in the New York Legislature during the $194^{2}$ session are of particular interest. One is designed for the City of New York, the other for the remaining 57 counties of the State. The procedure in these bills embodies the advantages of the juvenile court procedure and the necessary safeguards of the criminal court in one tribunal, attached to the children's court. The judge is given the opportunity to determine, on the basis of a preliminary examination, whether the youthful defendant were best treated by juvenile court methods or by a criminal trial. Both hearings are in the one court. There is no necessity for bargaining with the court, for accepting or suggesting pleas to a lesser crime or to a lesser degree of the same charge: all youths apprehended and brought before the court are in the first instance received as youthful offenders, and it is up to the court to raise the degree of seriousness of the offense by its refusal to accept the preliminary appellation and to demand instead that the youth stand trial.

It is urged that these New York Acts be given consideration by all those who believe with the writer that the Youth Court Act unfortunately perpetuates the method of the criminal trial for youths instead of introducing into the process the important protective and non-punitive characteristics of the juvenile court procedure. 